\title{
EVALUASI STRUKTUR SISTEM RANGKA GEDUNG DENGAN DINDING GESER BERBASIS KINERJA
}

\author{
Bobby Septianto ${ }^{1}$, Daniel Christianto ${ }^{2}$ dan Hadi Pranata ${ }^{3}$ \\ ${ }^{1}$ Program Studi Sarjana Teknik Sipil, Universitas Tarumanagara, Jl. Letjen S. Parman No.1 Jakarta \\ Email: bobbyseptianto@gmail.com \\ ${ }^{2}$ Program Studi Sarjana Teknik Sipil, Universitas Tarumanagara, Jl. Letjen S. Parman No.1 Jakarta \\ Email:daniel@untar.ac.id \\ ${ }^{3}$ Program Studi Sarjana Teknik Sipil, Universitas Tarumanagara, Jl. Letjen S. Parman No.1 Jakarta \\ Email: hp.rematha@gmail.com
}

\begin{abstract}
ABSTRAK
Indonesia merupakan daerah dengan resiko gempa tinggi, dimana dibutuhkan perencanaan tahan gempa. Struktur penahan gaya gempa secara umum memakai konsep Force Based Design. Konsep dari Force Based Design hanya berdasarkan kondisi elastis struktur dan tidak sesuai dengan kondisi sebenarnya dimana struktur gedung mengalami kondisi inelastis ketika mengalami guncangan gempa. Sehingga perlu dilakukan analisis evaluasi kinerja struktur untuk mengetahui kinerja gedung ketika mencapai kondisi inelastis yang merupakan konsep Performance Based Design. Dalam penelitian ini terdapat dua metode yang dipakai untuk analisis gedung ketika mengalami kondisi inelastis, yaitu metode Direct Displacement Based Design (DDBD) dan metode analisis statik nonlinier Pushover. Tujuan dalam penelitian ini untuk mengindentifikasi hasil output dari kurva kapasitas dan kinerja struktur dari metode ATC-40, FEMA 356, dan FEMA 440, serta membandingkan nilai gaya geser dasar antara SNI 1726:2012 dengan metode $D D B D$. Tipe struktur bangunan yang dimodelkan berupa bangunan sistem rangka gedung dengan dinding geser. Dari hasil analisis, untuk sistem rangka gedung dengan dinding geser, gaya geser dasar yang diperoleh dari perhitungan dengan metode Direct Dipslacement Based Design lebih kecil dari gaya geser dasar analisis gempa menurut SNI 1726:2012. Dari berbagai metode yang direncanakan sesuai dengan peraturan SNI 1726:2012 menghasilkan level kinerja yang sama menurut ATC-40, FEMA 356, dan FEMA 440 yaitu Immediate Occupancy.
\end{abstract}

Kata kunci: kinerja, inelastis, pushover, shearwall, direct displacement based design.

\section{PENDAHULUAN}

Indonesia merupakan negara yang secara geografis terletak pada pertemuan tiga lempeng tektonik dunia yaitu Eurasia, Indo-Australia dan Pasifik. Pergerakan antar lempeng tersebut menyebabkan sering terjadinya gempa bumi di Indonesia. Dalam mendesain bangunan tahan gempa, pemilihan sistem struktur merupakan hal yang sangat penting. Shearwall atau dinding geser memiliki peranan yang baik dalam menunjang ketahan gedung dalam menahan beban lateral.

Desain bangunan terhadap gempa saat ini menggunakan metode Force-Based Design (FBD), namun kelemahan dari metode ini adalah memakan banyak waktu (Priestley et al., 2007). Pada perencanaan berbasis gaya, kinerja struktur hanya memperlihatkan pada dua level, yaitu pada gempa-gempa kecil bangunan berada dalam keadaan siap pakai (servicebility limit state) sedangkan pada gempa rencana bangunan berada dalam keadaan rusak namun tidak runtuh (life safety).

Saat ini arah metode perencanaan bangunan tahan gempa beralih dari pendekatan gaya (force based) menuju pendekatan kinerja (performance based) dimana struktur direncanakan terhadap beberapa tingkat kinerja. Untuk mengatasi masalah dengan metode Force-Based Design (FBD) tersebut, dikembangkanlah metode lain sebagai alternatif, yaitu metode Direct Displacement Based Design (DDBD). Dalam metode DDBD besarnya gaya geser dasar ditentukan berdasarkan kekakuan efektif dan target perpindahan yang telah ditentukan menurut level kinerja struktur yang dikehendaki, dalam hal ini yaitu Life Safety (Drift Limit 2\%).

Untuk mengetahui kinerja struktur saat menerima beban gempa, maka dibutuhkan analisis nonlinier. Salah satu cara analisis nonlinear yang dapat digunakan adalah Capacity Spectrum Method yang memanfaatkan analisis beban dorong statis nonlinier (nonlinear static pushover analysis) yang menggunakan kinerja struktur sebagai sasaran perencanaan. Analisis pushover tersebut dianalisis berdasarkan peraturan ATC-40, FEMA 356, dan FEMA 440. 
Selain itu, analisis pushover juga dapat memperlihatkan secara visual perilaku struktur gedung saat kondisi elastis, plastis dan sampai terjadi keruntuhan pada elemen strukturnya.

\section{Gempa}

Gempa bumi merupakan fenomena getaran yang berkaitan dengan gesekan atau hentakan pada kerak bumi. Fenomena tersebut dapat disebabkan oleh beberapa hal, namun salah satu penyebab utamanya adalah pergesekan kerak bumi yang mempengaruhi permukaan bumi. Gesekan tersebut merambat dalam bentuk gelombang. Gelombang tersebut yang menyebabkan permukaan bumi dan bangunan di atasnya bergetar. Berdasarkan penyebabnya, secara umum gempa dibagi menjadi 3 jenis, yaitu : Gempa Tektonik, Gempa Vulkanik, dan Gempa Longsoran atau Ledakan.

\section{Perencanaan berbasis gaya}

Gempa akan menimbulkan getaran atau goyangan pada tanah ke segala arah dan menggetarkan bangunan yang berdiri di atas tanah tersebut. Pada dasarnya sebuah bangunan yang terkena gempa akan cenderung tidak bergerak karena mempertahankan bentuknya. Hal ini menimbulkan suatu gaya inersia pada bangunan. Force-Based Design menggunakan gaya inersia tersebut pada bangunan yang ditentukan oleh berat bangunan (Wt), koefisien modifikasi respons $(\mathrm{R})$, dan faktor reduksi gaya $(\mathrm{Cd})$.

\section{Static Equivalent}

Merupakan pembebanan gempa secara statis pada setiap lantai sebuah struktur bangunan yang besarnya ditentukan oleh massa lantai dan ketinggian lantai tersebut dari permukaan tanah, periode $(T)$ struktur bangunan tersebut serta faktor respons gempa (Cs) yang diambil berdasarkan SNI 1726-2012.

2. Response Spectrum

Adalah sebuah kurva respon dengan periode getar struktur $\mathrm{T}$ (sumbu $\mathrm{x}$ ) dan respon-respon maksimum berdasarkan rasio redaman dan gempa tertentu (sumbu y). Respon-respon maksimum dapat berupa simpangan maksimum (spectral displacement, SD), kecepatan maksimum (spectral velocity, SV) atau percepatan maksimum (spectral acceleration, SA), dan massa struktur Single Degree of Freedom (SDOF). Respon spektrum desain ditentukan dengan parameter respon ragam yang disesuaikan dengan klasifikasi situs dimana bangunan tersebut akan dibangun. Terdapat dua macam respons spektrum yang ada yaitu respons spektrum elastik dan respons spektrum inelastik. Spektrum elastik adalah suatu spektrum respons spektrum yang didasarkan atas respon elastik suatu struktur, sedangkan spektrum inelastik (juga disebut desain respons spektrum) adalah respon spektrum yang reduced scale dari spektrum elastik dengan nilai daktilitas tertentu.

\section{Perencanaan berbasis kinerja}

Kelemahan dari konsep berbasis gaya (force based) adalah tidak dapat diketahuinya tingkat kinerja struktur secara eksplisit pada kondisi inelastik karena analisis yang digunakan adalah analisis elastis. Tingkat kinerja struktur pada kondisi inelastik ini mulai diperhatikan pada suatu pendekatan terbaru dari konsep perencanaan bangunan tahan gempa yang dinamakan Performance Based Design.

Performance Based Design adalah suatu konsep dalam perencanaan dan analisis seismik struktur bangunan, menetapkan berbagai tingkat kinerja struktur. Tingkat kinerja ini adalah tingkat kinerja bangunan yang diharapkan terjadi pada saat struktur dilanda gempa dengan tingkat intensitas tertentu. Tingkat kinerja (performance) ini merupakan suatu pilihan yang harus ditentukan oleh perencanaan struktur pada tahap awal, dimana tingkat kinerja ini dapat dievaluasi dari beberapa kondisi batas.

Perencanaan berdasarkan konsep berbasis kinerja dapat dilakukan dengan metode Displacement Based Design. Hal terpenting yang perlu diperhatikan pada konsep performance based design adalah pemeriksaan kinerja benar-benar dilakukan secara eksplisit. Tujuan utama dari desain berbasis kinerja yaitu untuk menentukan tingkat kinerja yang diinginkan dari bangunan. Kinerja seismik digambarkan dengan menetapkan tingkat kerusakan maksimum yang diizinkan (performance level) untuk mengidentifikasi bahaya gempa.

\section{Analisis pushover}

Analisis statik nonlinier pushover (ATC-40, 1996) merupakan salah satu komponen performance based design yang menjadi sarana dalam mencari kapasitas dari suatu struktur. Dengan memberikan pola beban statik tertentu dalam arah lateral yang ditingkatkan secara bertahap pada suatu struktur sampai struktur tersebut mencapai target displacement tertentu atau mencapai pola keruntuhan tertentu. Dari hasil analisis tersebut dapat diketahui nilai-nilai gaya geser dasar untuk perpindahan lantai atap tertentu. Nilai-nilai yang didapatkan tersebut kemudian dipetakan menjadi kurva kapasitas dari struktur. Analisis pushover menghasilkan kurva pushover seperti pada Gambar 1, kurva yang menggambarkan hubungan antara gaya geser dasar (V) versus perpindahan titik acuan pada atap (D). Pada proses pushover, struktur didorong sampai mengalami leleh disatu atau lebih lokasi di struktur tersebut. 


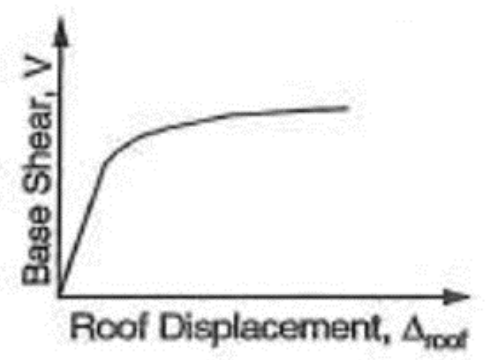

Gambar 1. Kurva Kapasitas Pushover

\section{Kinerja struktur metode $A T C-40$}

Berdasarkan ATC-40 kinerja struktur ( pada Gambar 2) bangunan gedung dapat dibagi menjadi beberapa kategori sebagai berikut :
a. Immediate Occupancy $(I O)$
b. Damage Control (DC)
c. Life Safety (LS)
d. Limited Safety
e. Structural Stability
f. Not Considered

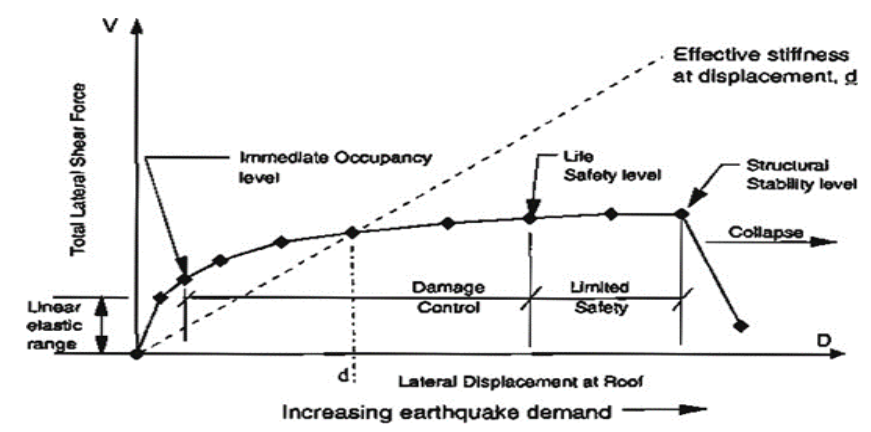

Gambar 2. Tipikal Kurva pada Berbagai Tingkat Kinerja Struktur (ATC-40, 1996 : 6-2)

Deformasi lateral pada saat performance point harus dicek terhadap deformasi limit yang ditetapkan dalam ATC-40, 1996 Bab 11.3.3. Deformasi limit pada berbagai tingkat kinerja dilihat pada Tabel 1 berikut.

Tabel 1. Batasan Simpangan pada Tingkat Kinerja Struktur (ATC-40, $1996: 11-4)$

\begin{tabular}{lcccc}
\hline \multicolumn{5}{c}{ Tingkat Kinerja } \\
\hline Batas Simpangan & Immediate Occupancy & Damage Control & Life Safety & Structural Stability \\
\hline Maximum Total Drift & 0.01 & $0.01-0.02$ & 0.02 & 0.33 Vi/Pi \\
\hline Maximum Inelastic Drift & 0.005 & $0.005-0.015$ & No Limit & No Limit \\
\hline
\end{tabular}

\section{Kinerja struktur metode FEMA 356 dan FEMA 440}

Berdasarkan FEMA 356 maka kinerja struktur bangunan saat terjadi gempa dibagi menjadi beberapa kategori dapat dilihat pada Gambar 3. Tingkat kinerja FEMA ini secara garis besar adalah sama dengan tingkat kinerja dalam ATC40.

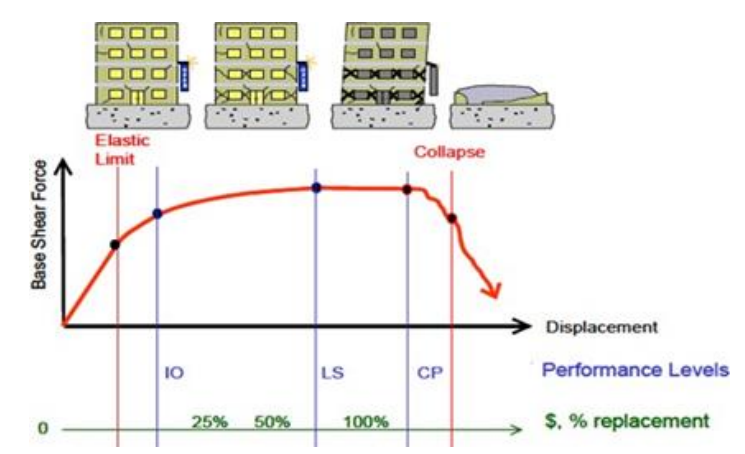

Gambar 3. Tingkat Kinerja Struktur (FEMA 273, 1997) 
Metode koefisien FEMA 356 dan 440 adalah suatu pendekatan yang menyediakan perhitungan numerik langsung dari perpindahan global maksimum pada struktur. Penyelesaian dilakukan dengan memodifikasi respon elastis dari sistem SDOF ekuivalen dengan faktor koefisien $C_{0}, C_{1}, C_{2}, C_{3}$ sehingga diperoleh perpindahan global maksimum (elastis dan inelastis) yang disebut target perpindahan $\left(\delta_{T}\right)$.

\section{Direct displacement based design}

Beban gempa akan menyertakan gaya dan perpindahan pada struktur. Kemampuan struktur berdeformasi pada respon elastik akan berhubungan langsung dengan kekakuan sistem, tapi untuk struktur pada respon inelastik, maka hubungannya akan menjadi rumit, sehingga akan tergantung pada perpindahan sesaat juga riwayat perpindahan selama respon gempa (Priestley et al. 2007: 1).

Dalam desain berbasis gaya, beban gempa desain didesain pada saat respon elastik, akan tetapi dalam keadaan yang sebenarnya struktur akan mampu untuk menyerap energi gempa (dissipating energy) dalam bentuk deformasi inelastik, sehingga dalam desain berbasis gaya ini diberikan faktor modifikasi respon, $R$. Faktor modifikasi respon ini adalah perbandingan nilai gaya pada saat respon elastik dengan gaya desain.

Metode Direct Displacement Based Design (DDBD) muncul untuk mengatasi kelemahan-kelemahan dalam desain berbasis gaya. Metode $D D B D$ menekankan nilai perpindahan sebagai acuan untuk menentukan kekuatan yang diperlukan bangunan terhadap gempa desain. Perbedaan mendasar dari metode Force Based Design adalah DDBD ditandai dengan struktur akan didesain oleh suatu derajat kebebasan (Single Degree of Freedom/SDOF) dengan representasi dari kinerja pada respon perpindahan puncak, bukan oleh karakteristik elastik awal. Konsep desain berbasis perpindahan Direct Displacement Based Design secara umum diilustrasikan pada Gambar 4 berikut.

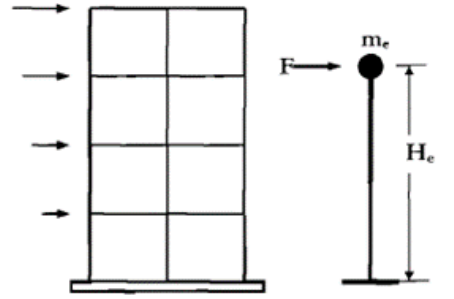

(a) SDOF Simulation

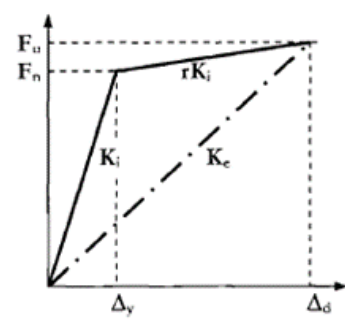

(b) Effective Stiffncss $K_{\mathrm{e}}$

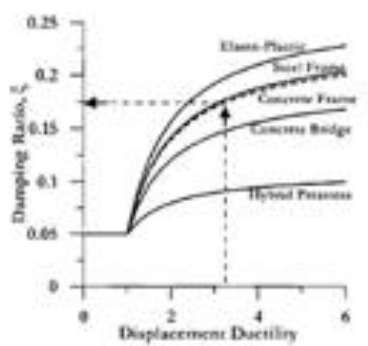

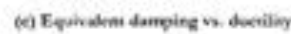

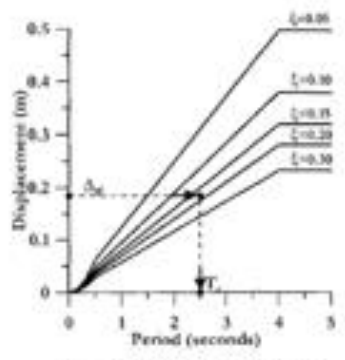

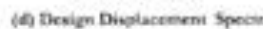

Gambar 4. Konsep Direct Displacement Based Design

\section{METODOLOGI PENELITIAN}

Pada penelitian ini, pemodelan, analisis, dan desain dilakukan dengan menggunakan program ETABS, struktur dimodelkan sebagai struktur 3D dengan sistem struktural balok, kolom, dan dinding geser. Perencanaan awal struktur direncanakan menurut SNI 1726:2012.

\section{Deskripsi umum struktur}

Akan dimodelkan gedung 12 lantai (32 m x $48 \mathrm{~m}$ ) seperti nampak pada Gambar 5 yang direncanakan berdasarkan sistem rangka gedung dengan dinding geser beton yang dominan menahan beban lateral sesuai dengan peraturan gempa SNI 1726:2012. Pemodelan struktur akan dilakukan dengan bantuan peranti lunak ETABS. Berikut rangkuman data model struktur pada Tabel 2.
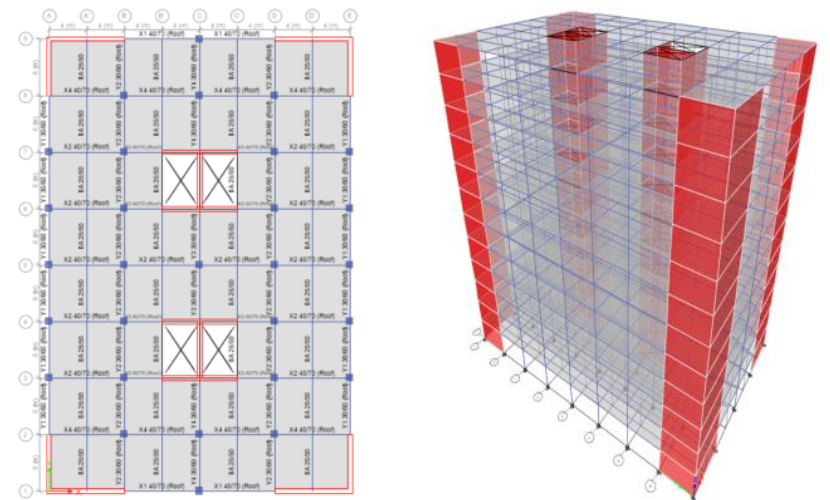

Gambar 5. Tampak Atas dan Tiga Dimensi Struktur Rencana 
Tabel 2. Data Model Struktur Gedung

\begin{tabular}{cc}
\hline Fungsi Bangunan & Perkantoran \\
\hline Lokasi & Surabaya \\
\hline Jumlah Lantai & 12 Lantai \\
\hline Tinggi Total & $48 \mathrm{~m}$ \\
\hline Sistem Struktur & Sistem Rangka + Dinding Geser \\
\hline
\end{tabular}

\section{Prosedur analisis}

Pembahasan ini, pertama-tama penulis akan menjabarkan proses analisis gempa sesuai SNI 1726:2012. Dimana gaya gempa yang diperoleh digunakan untuk perencanaan model struktur yang akan dievaluasi kinerjanya dengan metode analisis pushover.

Pada saat analisis gempa, akan dilakukan perhitungan gaya gempa statik ekuivalen, lalu dilakukan perhitungan gaya gempa dinamik dengan metode spektrum respons ragam oleh program ETABS. Selanjutnya adalah penentuan gaya gempa rencana yang merupakan gaya gempa envelope diantara gaya gempa statik ekuivalen dan gaya gempa dinamik. Gaya gempa rencana akan di-input pada program ETABS untuk dilakukan perencanaan kebutuhan tulangan yang akan dievaluasi kinerja strukturnya dengan metode analisis pushover.

Dalam analisis pushover akan dilihat pola keruntuhan pada model struktur dan mencari nilai target perpindahan beserta kinerjanya dengan metode menurut ATC-40 (Metode Kapasitas Spektrum), metode menurut FEMA 356 (Metode Koefisien Perpindahan) dan metode menurut FEMA 440.

Kemudian dengan metode DDBD (Direct Displacement Based Design) akan direncanakan gaya gempa rencana dengan kinerja struktur rencana yaitu Life Safety yang akan dibandingkan dengan metode analisis pushover. Diagram alir untuk penelitian ini bisa dilihat pada Gambar 5.

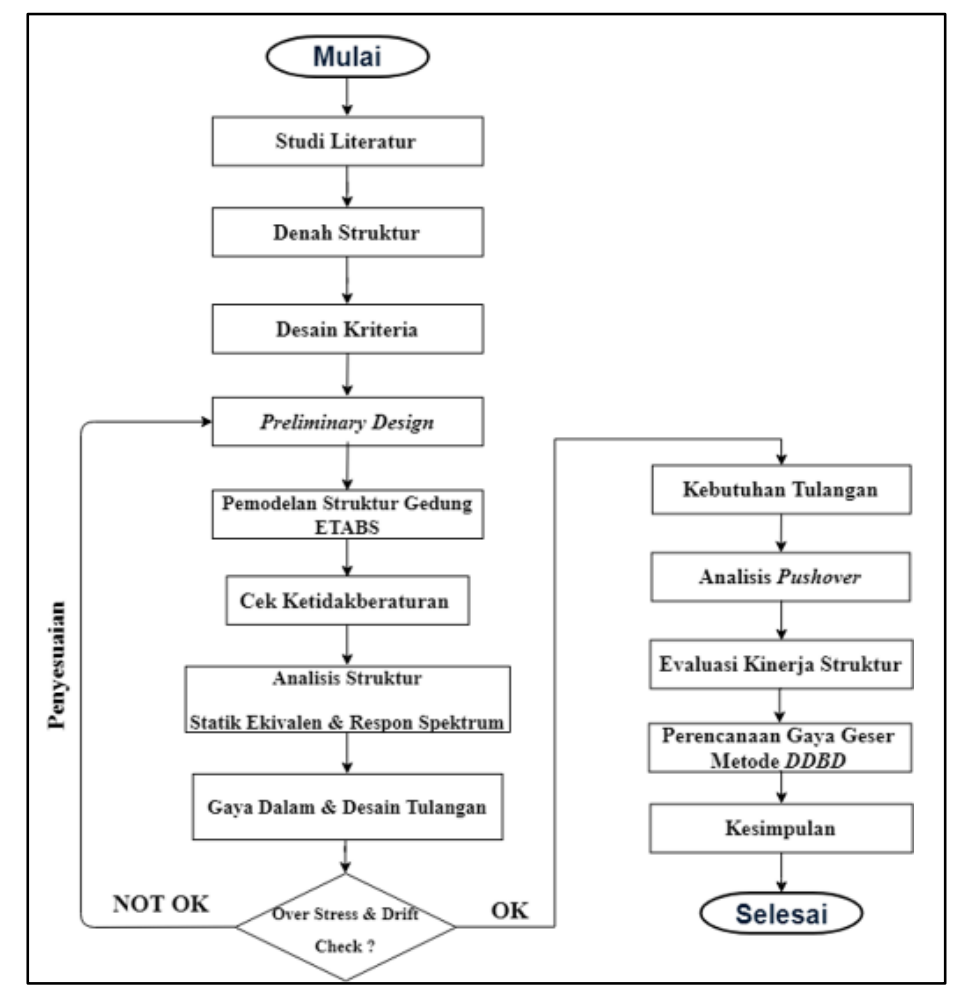

Gambar 5. Diagram Alir Penelitian

\section{ANALISIS DAN PEMBAHASAN}

\section{Analisis gempa rencana}

Untuk menghitung gaya gempa rencana dilakukan perhitungan gaya gempa statik ekivalen dan dinamik respons spektrum. Maka selanjutnya akan dihitung gaya gempa rencana yang merupakan gaya gempa terbesar dari gaya gempa statik dan gaya gempa dinamik (envelope). Berikut hasil perhitungan perolehan gaya gempa rencana pada Tabel 3. 
Tabel 3. Gaya Gempa Rencana

\begin{tabular}{|c|c|c|c|c|c|c|c|c|c|c|c|c|}
\hline \multirow{3}{*}{$\mathrm{Lt}$} & \multirow{2}{*}{\multicolumn{2}{|c|}{$\begin{array}{c}\text { Analisis Statik } \\
\text { Gaya Geser KN }\end{array}$}} & \multirow{2}{*}{\multicolumn{2}{|c|}{$\begin{array}{c}\text { Analisis Dinamik } \\
\text { Gaya Geser KN }\end{array}$}} & \multirow{2}{*}{\multicolumn{2}{|c|}{ Faktor Skala }} & \multirow{2}{*}{\multicolumn{2}{|c|}{$\begin{array}{c}\text { Dinamik Terfaktor } \\
\text { Gaya Geser KN } \\
\end{array}$}} & \multicolumn{4}{|c|}{ GAYA GEMPA RENCANA } \\
\hline & & & & & & & & & \multicolumn{2}{|c|}{ Gaya Geser KN } & \multicolumn{2}{|c|}{ Gaya Lateral KN } \\
\hline & $0.85 \mathrm{Vx}$ & $0.85 \mathrm{Vy}$ & Vx & $\mathrm{Vy}$ & Fsx & Fsy & $\mathrm{Vx}$ & Vy & Vix & Vi y & $\mathrm{Fx}$ & F y \\
\hline 12 & 1779.06 & 1619.47 & 1717.61 & 1571.75 & 1.217 & 1.187 & 2089.78 & 1865.97 & 2089.78 & 1865.97 & 2089.78 & 1865.97 \\
\hline 11 & 4469.64 & 4051.39 & 4144.67 & 3757.30 & 1.217 & 1.187 & 5042.74 & 4460.65 & 5042.74 & 4460.65 & 2952.96 & 2594.68 \\
\hline 10 & 6884.58 & 6217.29 & 6176.56 & 5557.86 & 1.217 & 1.187 & 7514.90 & 6598.26 & 7514.90 & 6598.26 & 2472.16 & 2137.61 \\
\hline 9 & 9027.57 & 8122.83 & 7883.58 & 7050.47 & 1.217 & 1.187 & 9591.79 & 8370.28 & 9591.79 & 8370.28 & 2076.89 & 1772.02 \\
\hline 8 & 10902.61 & 9774.19 & 9325.94 & 8302.16 & 1.217 & 1.187 & 11346.68 & 9856.28 & 11346.68 & 9856.28 & 1754.89 & 1486.00 \\
\hline 7 & 12514.18 & 11178.15 & 10547.52 & 9367.78 & 1.217 & 1.187 & 12832.94 & 11121.38 & 12832.94 & 11178.15 & 1486.27 & 1321.87 \\
\hline 6 & 13867.28 & 12342.22 & 11579.09 & 10280.65 & 1.217 & 1.187 & 14088.04 & 12205.13 & 14088.04 & 12342.22 & 1255.10 & 1164.07 \\
\hline 5 & 14967.65 & 13274.91 & 12432.46 & 11053.97 & 1.217 & 1.187 & 15126.32 & 13123.21 & 15126.32 & 13274.91 & 1038.28 & 932.69 \\
\hline 4 & 15822.01 & 13986.03 & 13102.87 & 11684.43 & 1.217 & 1.187 & 15941.99 & 13871.69 & 15941.99 & 13986.03 & 815.67 & 711.12 \\
\hline 3 & 16438.56 & 14487.30 & 13582.60 & 12155.42 & 1.217 & 1.187 & 16525.66 & 14430.85 & 16525.66 & 14487.30 & 583.68 & 501.28 \\
\hline 2 & 16827.85 & 14793.53 & 13868.80 & 12452.11 & 1.217 & 1.187 & 16873.88 & 14783.07 & 16873.88 & 14793.53 & 348.21 & 306.22 \\
\hline 1 & 17005.23 & 14925.39 & 13976.76 & 12571.99 & 1.217 & 1.187 & 17005.23 & 14925.39 & 17005.23 & 14925.39 & 131.35 & 131.87 \\
\hline
\end{tabular}

\section{Analisis pushover}

Dari output analisis pushover didapatkan kurava kapasitas dari struktur, selanjutnya dari kurva kapasitas tadi dievaluasi kinerjanya dengan 3 metode yaitu ATC-40, FEMA 356, dan FEMA 440. Kurva kapasitas hasil analisis pushover untuk masing-masing arah bisa dilihat pada Gambar 6 berikut.

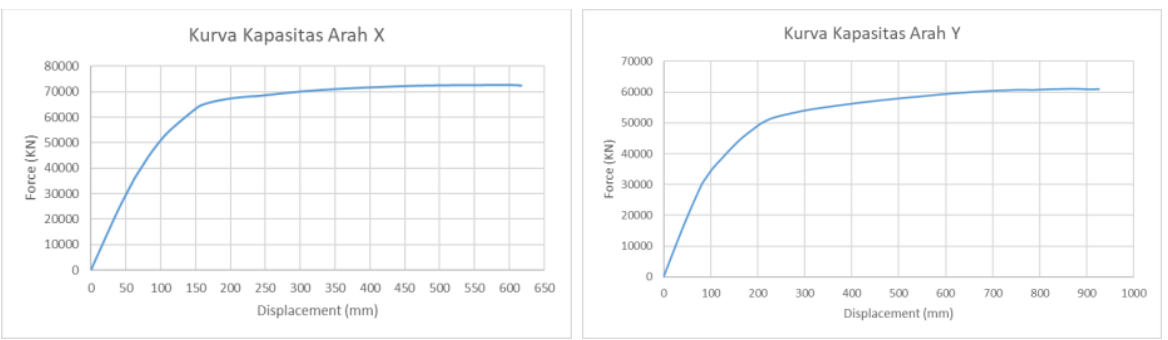

Gambar 6. Kurva Kapasitas Arah X dan Arah Y

\section{Evaluasi kinerja struktur}

Evaluasi kinerja struktur digunakan untuk menentukan tingkat kinerja struktur yang didesain. Didapatkan 3 nilai kinerja struktur berdasarkan 3 peraturan yang umum digunakan yaitu ATC-40, FEMA 356, dan FEMA 440. Hasil nilai target perpindahan dan nilai drift dari masing-masing metode bisa dilihat pada Tabel 4 berikut ini.

Tabel 4. Target Perpindahan dan Level Kinerja Struktur

\begin{tabular}{|c|c|c|c|c|c|}
\hline \multirow{3}{*}{ Arah } & \multirow{3}{*}{ Parameter } & \multicolumn{4}{|c|}{ Analisis Pushover } \\
\hline & & \multicolumn{2}{|c|}{ Metode Spektrum Kapasitas } & \multicolumn{2}{|c|}{ Metode Koefisien Perpindahan } \\
\hline & & $A T C-40$ & FEMA 440 & FEMA 356 & FEMA 440 \\
\hline \multirow{3}{*}{$\begin{array}{c}\text { Arah } \\
\text { X }\end{array}$} & $\begin{array}{l}\text { T. Perpindahan } \\
(\mathrm{m})\end{array}$ & 0.086796 & 0.21354 & 0.253 & 0.209 \\
\hline & Drift & 0.00181 & 0.00445 & 0.0053 & 0.00434 \\
\hline & Level Kinerja & $\begin{array}{l}\text { Immediate } \\
\text { Occupancy }\end{array}$ & $\begin{array}{l}\text { Immediate } \\
\text { Occupancy }\end{array}$ & $\begin{array}{l}\text { Immediate } \\
\text { Occupancy }\end{array}$ & $\begin{array}{l}\text { Immediate } \\
\text { Occupancy }\end{array}$ \\
\hline \multirow{3}{*}{$\begin{array}{c}\text { Arah } \\
\mathrm{Y}\end{array}$} & $\begin{array}{l}\text { T. Perpindahan } \\
\text { (m) }\end{array}$ & 0.093897 & 0.2871 & 0.295 & 0.271 \\
\hline & Drift & 0.00196 & 0.00598 & 0.00612 & 0.00565 \\
\hline & Level Kinerja & $\begin{array}{l}\text { Immediate } \\
\text { Occupancy }\end{array}$ & $\begin{array}{l}\text { Immediate } \\
\text { Occupancy }\end{array}$ & $\begin{array}{l}\text { Immediate } \\
\text { Occupancy }\end{array}$ & $\begin{array}{l}\text { Immediate } \\
\text { Occupancy }\end{array}$ \\
\hline
\end{tabular}

\section{Analisis gempa metode direct displacement based design}

1. Distribusi Gaya Geser Dasar pada Frame dan Shearwall

Dalam menentukan rasio proporsi gaya geser dasar pada frame dan shearwall, struktur yang dimodelkan dengan program bantu ETABS diberikan pola beban gempa menurut respon spektrum ragam. Dari perhitungan didapat 
rasio gaya geser frame dan shearwall untuk arah X adalah $5.54 \%$ dan $94.46 \%$ sedangkan untuk arah $\mathrm{Y}$ adalah $7.42 \%$ dan $92.58 \%$.

2. Tinggi $\mathrm{RC}$-Wall Contraflexure $(\mathrm{Hcf})$

Tinggi Hcf dihitung berdasarkan nilai overturning moment relatif yang terjadi pada dinding geser. Namun karena dinding lebih dominan menahan gaya lateral dan frame sangat kecil, maka mengakibatkan nilai overturning moment pada wall berada pada ketinggian yang sama dengan tinggi struktur yaitu $\mathrm{Hcf}=48 \mathrm{~m}$.

3. Profil Perpindahan Leleh Dinding Geser

Profil perpindahan leleh dinding geser ditentukan oleh karakteristik panjang dinding geser, $8 \mathrm{~m}$ untuk tinjau arah X dan $6 \mathrm{~m}$ tinjau arah Y. Nilai dari profil perpindahan leleh ini dipengaruhi oleh nilai kelengkungan leleh pada dasar dinging geser, ФyWall. Sehingga, nilai dari profil perpindahan leleh dinding geser ditentukan berdasarkan rumus berikut.

$$
\Delta_{y i}=\phi_{y W a l l}\left(\frac{H i^{2}}{2}-\frac{H i^{3}}{6 H_{C F}}\right)=0.00055 x\left(\frac{H i^{2}}{2}-\frac{H i^{3}}{6 \times 48}\right)
$$

Dimana $\Phi y W a l l=$ kelengkungan leleh dasar dinding, $\mathrm{Hi}=$ tinggi tingkat level-I, dan Hcf = tinggi contraflexure .

4. Desain Profil Perpindahan Rencana $\left(\Delta_{\mathrm{Di}}\right)$

Nilai dari profil perpindahan rencana ini dipengaruhi oleh faktor drift limit, $\theta$ c, yaitu sebesar 0.02 (Life Safety). Pada penelitian ini nilai dari profil perpindahan rencana pada perencanaan Life Safety, yang didapat dari rumus berikut.

$$
\Delta D i=\Delta y i+\left(\theta c-\frac{\Phi y W a l l x H c f}{2}\right) x H i
$$

Berikut ini adalah hasil dari perhitungan profil perpindahan rencana untuk arah $\mathrm{X}$ dan $\mathrm{Y}$ yang bisa dilihat pada Tabel 5 berikut.

Tabel 5. Perhitungan Profil Perpindahan Rencana Arah X dan Arah Y

\begin{tabular}{ccccccccccccc}
\hline \multicolumn{1}{c}{ Arah X } & \multicolumn{5}{c}{ Arah Y } \\
\hline Lt & Tinggi & Mass & $\Delta$ yi & $\Delta$ Di & Mi $\Delta$ Di2 & Mi $\Delta$ Di & Mi $\Delta$ Di Hi & $\Delta y i$ & $\Delta$ Di & Mi $\Delta$ Di2 & Mi $\Delta$ Di & Mi $\Delta$ Di Hi \\
\hline & Hi $(\mathrm{m})$ & Mi (Ton) & $(\mathrm{m})$ & $(\mathrm{m})$ & & & & $(\mathrm{m})$ & $(\mathrm{m})$ & & & \\
\hline 12 & 48 & 1021.39 & 0.42 & 0.73 & 539.07 & 742.02 & 35617.17 & 0.56 & 0.65 & 437.15 & 668.21 & 32073.87 \\
\hline 11 & 44 & 1704.91 & 0.37 & 0.65 & 716.93 & 1105.58 & 48645.33 & 0.49 & 0.58 & 566.41 & 982.69 & 43238.48 \\
\hline 10 & 40 & 1704.91 & 0.32 & 0.57 & 556.22 & 973.81 & 38952.48 & 0.42 & 0.50 & 425.45 & 851.68 & 34067.25 \\
\hline 9 & 36 & 1704.91 & 0.27 & 0.50 & 418.36 & 844.55 & 30403.76 & 0.36 & 0.42 & 307.45 & 724.00 & 26064.15 \\
\hline 8 & 32 & 1704.91 & 0.22 & 0.42 & 303.25 & 719.04 & 23009.17 & 0.29 & 0.35 & 212.09 & 601.33 & 19242.49 \\
\hline 7 & 28 & 1704.91 & 0.17 & 0.35 & 210.12 & 598.53 & 16758.71 & 0.23 & 0.28 & 138.15 & 485.32 & 13588.95 \\
\hline 6 & 24 & 1704.91 & 0.13 & 0.28 & 137.55 & 484.27 & 11622.37 & 0.18 & 0.22 & 83.65 & 377.65 & 9063.52 \\
\hline 5 & 20 & 1704.91 & 0.09 & 0.22 & 83.59 & 377.51 & 7550.15 & 0.13 & 0.16 & 45.98 & 279.98 & 5599.52 \\
\hline 4 & 16 & 1704.91 & 0.06 & 0.16 & 45.82 & 279.50 & 4472.02 & 0.08 & 0.11 & 22.07 & 193.97 & 3103.59 \\
\hline 3 & 12 & 1704.91 & 0.04 & 0.11 & 21.51 & 191.50 & 2297.96 & 0.05 & 0.07 & 8.63 & 121.31 & 1455.71 \\
\hline 2 & 8 & 1704.91 & 0.02 & 0.07 & 7.72 & 114.75 & 917.96 & 0.02 & 0.04 & 2.38 & 63.65 & 509.17 \\
\hline 1 & 4 & 1704.91 & 0.00 & 0.03 & 1.50 & 50.50 & 201.98 & 0.01 & 0.01 & 0.30 & 22.65 & 90.62 \\
\hline SUM & & 19775.44 & & & 3041.63 & 6481.54 & 220449.06 & & & 2249.71 & 5372.44 & 188097.31 \\
\hline & & & & & & & & & & & &
\end{tabular}

5. Desain Perpindahan SDOF

Desain perpindahan dari sistem SDOF (Single Degree of Freedom) untuk arah X sebesar $0.4693 \mathrm{~m}$ dan arah Y sebesar $0.4188 \mathrm{~m}$, didapat dari rumus berikut.

$$
\Delta_{d}=\frac{\sum_{i=1}^{n}\left(m i \Delta i^{2}\right)}{\sum_{i=1}^{n}(m i \Delta i)}
$$

Dimana $\mathrm{mi}=$ massa tingkat- $\mathrm{I}, \Delta \mathrm{i}=\Delta \mathrm{Di}=$ perpindahan rencana . 
6. Tinggi Efektif

Didapat untuk arah X tinggi efektif sebesar 34.0119 m dan arah Y sebesar $35.0115 \mathrm{~m}$. Tinggi efektif, He, dari sistem SDOF untuk arah X dan arah Y dihitung dengan menggunakan rumus sebagai berikut :

$$
H_{e}=\frac{\sum_{i=1}^{n}(m i \Delta i h i)}{\sum_{i=1}^{n}(m i \Delta i)}
$$

dimana $\mathrm{mi}=$ massa tingkat $-\mathrm{I}, \Delta \mathrm{i}=\Delta \mathrm{Di}=$ perpindahan rencana, dan hi $=$ tinggi tingkat level-i.

7. Massa Efektif $\left(\mathrm{m}_{\mathrm{e}}\right)$

Massa efektif dari sistem SDOF untuk arah X didapat sebesar 13811.78 Ton/g, dan untuk arah Y sebesar 12829.68 Ton/g. Massa efektif diapat dari rumus berikut.

$$
m_{e}=\frac{\sum_{i=1}^{n}(m i \Delta i)}{\Delta_{d}}
$$

8. Redaman Efektif Ekivalen Sistem

Karena sistem struktur terdiri dari frame dan dinding geser, maka dicari nilai redaman efektif ekivalen dari gabungan kedua sistem tersebut, redaman efektif ekivalen untuk arah X didapat sebesar $11.45 \%$ dan untuk arah Y sebesar $7.68 \%$. Nilai redaman efektif ekivalen, $\xi e q$, dapat dicari dengan rumus berikut.

$$
\xi e q=\frac{M_{\text {OTM.W }} \xi W a l l+M_{\text {OTM.F }} \xi \text { Frame }}{M_{\text {OTM }}}
$$

Dimana $\mathrm{M}_{\mathrm{OTM}}=$ momen total, $\mathrm{M}_{\mathrm{OTM} . \mathrm{F}}=$ momen frame, $\mathrm{M}_{\mathrm{OTM} . \mathrm{W}}=$ momen wall, dan $\xi$ Wall, Frame = redaman elemen dinding dan rangka.

9. Periode Efektif (Teff)

Nilai periode efektif ini didapat dari reduksi respon spektra displacement dengan redaman 5\%, yang di reduksi dengan nilai redaman ekivalen masing-masing arah. Grafik nilai periode efektif arah X dan Y bisa dilihat pada Gambar 7 berikut.

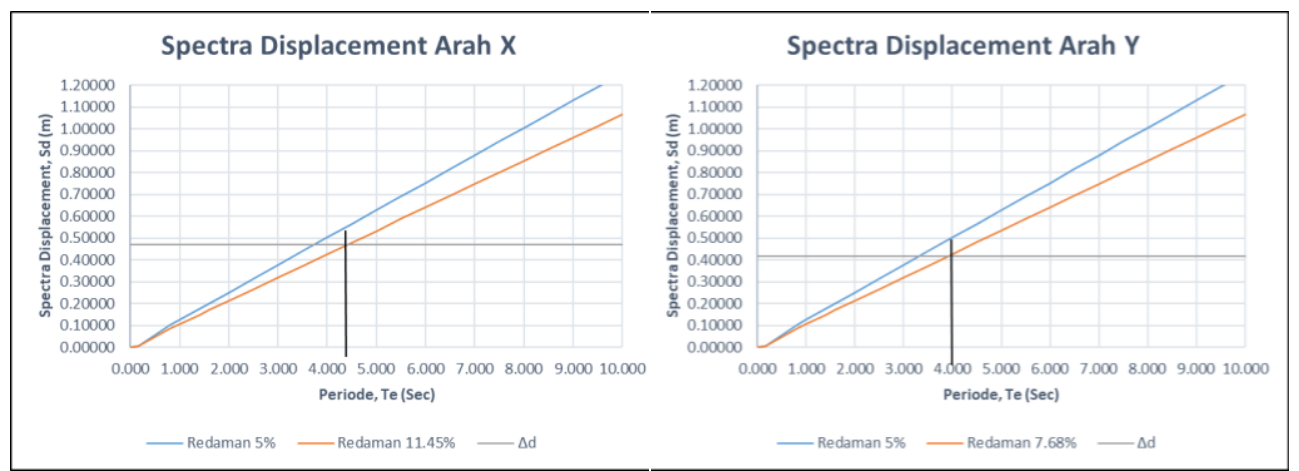

Gambar 7. $\mathrm{T}_{\text {eff }}$ Spectral Displacement pada Redaman Arah X dan Y

10. Kekakuan Efektif

Nilai kekakuan efektif dari masing-masing arah bergantung dari selain dari massa efektifnya juga dari periode efektif $\left(\mathrm{T}_{\text {eff }}\right)$, Nilai dari kekakuan untuk arah $\mathrm{X}$ didapat sebesar $28815.81 \mathrm{KN} / \mathrm{m}$ dan untuk arah $\mathrm{Y}$ sebesar $31655.96 \mathrm{KN} / \mathrm{m}$. Dapat dicari dengan rumus berikut.

$$
K e=\frac{4 x \pi^{2} x m e}{T e f f^{2}}
$$

11. Gaya Geser Dasar $\left(\mathrm{V}_{\text {Base }}\right)$

Nilai gaya geser dapat ditentukan dengan mengalikan nilai kekakuan efektif (Ke) dengan nilai perpindahan rencana $(\Delta \mathrm{d})$. Didapat nilai gaya geser dasar untuk arah $\mathrm{X}$ dan $\mathrm{Y}$ yang dibandingkan dengan nilai gaya geser dasar dari metode SNI 1726:2012 bisa dilihat pada Tabel 6 berikut ini.

Tabel 6. Hasil Perbandingan Gaya Geser Rencana

\begin{tabular}{ccc}
\hline \multirow{2}{*}{ Gaya Geser Dasar Rencana } & SNI 1726:2012 & Metode DDBD \\
\cline { 2 - 3 } & $\mathrm{KN}$ & $\mathrm{KN}$ \\
\hline Arah X & 17005.23 & 13522.57 \\
\hline Arah Y & 14925.39 & 13255.96 \\
\hline
\end{tabular}




\section{KESIMPULAN DAN SARAN}

\section{Kesimpulan}

Berdasarkan hasil analisis yang telah dilakukan, dapat disimpulkan beberapa hal yaitu:

1. Dari hasil analisis, untuk sistem rangka gedung dengan dinding geser, gaya geser dasar yang diperoleh dari perhitungan dengan metode Direct Dipslacement Based Design lebih kecil dari gaya geser dasar analisis gempa menurut SNI 1726:2012.

2. Dalam analisis pushover, didapat bahwa semua struktur balok leleh terlebih dahulu kemudian kolom pada lantai dasar, sehingga sesuai dengan teori Strong Column Weak Beam.

3. Dari berbagai metode yang direncanakan sesuai dengan peraturan SNI 1726:2012 menghasilkan level kinerja yang sama menurut ATC-40, FEMA 356, dan FEMA 440 yaitu Immediate Occupancy.

4. Nilai target perpindahan dari metode FEMA 356 dan FEMA 440 lebih besar dari nilai target perpindahan hasil metode ATC-40, yang mana menunjukan bahwa metode FEMA 356 dan FEMA 440 sudah lebih baik karena semakin dekat dengan kinerja rencana yaitu Life Safety.

\section{Saran}

Berdasarkan hasil analisis yang dilakukan, maka saran yang dapat diberikan penulis yaitu:

1. Dalam analisis pushover, jumlah step sangat menentukan proses iterasi, sehingga jumlah step yang lebih banyak akan menghasilkan kurva yang lebih detail.

2. Perlu dipelajari lebih lanjut tentang berbagai formasi penempatan Shearwall yang efisien dalam perencanaan berbasis kinerja metode $D D B D$.

3. Perlu dipelajari lebih jauh tentang tipe-tipe sistem struktur lain dalam perencanaan berbasis kinerja.

4. Dapat dilakukan optimasi terhadap hasil desain karena kinerja struktur masih menunjukan level kinerja yang terlalu baik untuk beban gempa rencana. Optimasi dapat dilakukan dengan mengoptimalkan dimensi serta penulangan elemen.

\section{DAFTAR PUSTAKA}

ASCE 7-10. (2010). Minimum Design Loads for Buildings and Other Structures. Virginia: American Society of Civil Engineers.

ATC-40. (1996). Seismic Evaluation and Retrofit of Concrete Buildings. California: Applied Technology Council.

Badan Standararisasi Nasional. (2012). Tata Cara Perencanaan Ketahanan Gempa untuk Struktur Bangunan Gedung dan non Gedung (SNI 1726:2012). Jakarta: Badan Standarisasi Nasional.

Badan Standarisasi Nasional. (2013). Persyaratan Beton Struktural untuk Bangunan Gedung (SNI 2847:2013). Jakarta: Badan Standarisasi Nasional.

Computers and Structures, Inc. (2016). Csi Analysis Reference Manual. California: Computers and Structures, Inc.

FEMA 356. (2000). Prestandard and Commentary for the Seismic Rehabilitation of Buildings. Wasington, D.C: Federal Emergency Management Agency.

FEMA 440. (2005). Improvement of Nonlinier Static Seismic Analysis Procedures. Wasington, D.C: Federal Emergency Management Agency.

Paulay, T.; and Priestley, M.J.N.; (1992). Seismic Design of Reinforced Concrete and Masonry Buildings. New York: John Wiley dan Sons, Inc.

Priestley, M.J.N.; Calvi, G.M.; dan Kowalsky, M.J. (2007). Displacement-Based Seismic Design of Structures. Pavia: IUSS Press.

Priestley, M.J.N.; Calvi, G.M.; dan Kowalsky, M.J. (2008). Displacement-Based Seismic Design of Structures. USA: North Carolina State University.

Tavio, dan Wijaya, U. (2018). Desain Rekayasa Gempa Berbasis Kinerja. Jakarta: ANDI Yogyakarta. 

